JURNAL ILMU KELAUTAN KEPUlAUAN, 2 (1) ;32-41, JUNi 2019

\title{
PENENTUAN UKURAN MATA JARING INSANG DASAR (BOTTOM GILLNET) PADA KOMUNITAS IKAN TERUMBU KARANG DI PULAU DONROTU DESA SIDANGOLI DEHE KECAMATAN JAILOLO SELATAN KABUPATEN HALMAHERA BARAT
}

\author{
Darmawaty $^{1}$, Rina ${ }^{2}$, Salim Abubakar ${ }^{3}$ \\ ${ }^{1}$ Program Studi Pemanfaatan Sumberdaya Perikanan Fakultas Perikanan dan Ilmu \\ Kelautan Unkhair,Ternate, 97721, Indonesia \\ ${ }^{2,3}$ Program Studi Manajemen Sumberdaya Perairan Fakultas Perikanan dan Ilmu Kelautan \\ Unkhair,Ternate, 97721, Indonesia \\ E-mail: rinamuhamad79@gmail,com,darmawaty.kakalu@gmail.com
}

\begin{abstract}
ABSTRAK
Tujuan penelitian yaitumengetahui jenis-jenis ikan yang hidup di terumbu karang yang tertangkap dengan jaring insang dasar di Pulau Donrotu Desa Sidangoli Dehe, mengetahui struktur komunitas ikan pada ekosistem terumbu karang yang meliputi keanekaragaman jenis, dominasi jenis, kemerataan jenis) di Pulau Donrotu Desa Sidangoli Dehe dan menentukan ukuran mata jaring minum dari alat tangkap bottom gillnet yang dioperasikan pada ekosistem terumbu karang di Pulau Donrotu Desa Sidangoli Dehe. Pengambilan sampel dengan mengikuti kegiatan operasi penangkapan.dengan nelayan. Jaring dioperasikan pada waktu siang dan malam hari pada saat air bergerak pasang. Lama perendaman alat selama 2 jam. Penangkapan dilakukan sebanyak 12 kali ulangan artinya satu kali ulangan sama dengan satu trip. Penempatan jaring pada areal terumbu karang sesuai perlakuan dengan melintang atau searah garis pantai.Komposisi jenis ikan terumbu karang sebanyak 10 jenis yaituSiganus canaliculatuis, Siganus spinus, Siganus chysospilos, Scarus fraenatus, Scarus quoyi,Lutjanus gibbus, Pristipomoides auricillia, Epinephelus quoyanus, Mulloidichtys flavolineatus dan Rhinecanthus verrucosus. Keanekaragaman jenis ikan yang tertangkap pada ekosistem terumbu karang di Pulau Donrotu tergolong sedang, dan tidak ada jenis yang mendominasi serta penyebaran jenisnya sangat merata.Ukuran mata jaring minimum bottom gillnet untuk penangkapan ikan pada ekosistem terumbu karang dengan ukuran ikan sedang menggunakan jaring dengan mesh size 3,78 inchi dan ikan besar, lebar dan tinggi dengan mesh size 5,30 inchi serta ikan yang panjang dan pipih dengan mesh size 2,65 ichi.
\end{abstract}

Kata Kunci : Ikan karang, ukuran mata jaring, Pulau Donrotu

\section{ABSTRACT}

The research objective is to find out the types of fish that live on coral reefs caught with basic gill nets on Donrotu Island, Sidangoli Dehe Village, to know the structure of fish communities in coral reef ecosystems which include species diversity, species dominance, evenness) on Donrotu Island, Sidangoli Village Dehe and determine the size of the drinking net from Gillnet's bottom catcher tool which is operated on the coral reef ecosystem on Donrotu Island, Sidangoli Village Dehe. Sampling by participating in fishing operations with fishermen. Nets are operated during the day and night when the water moves tide. Duration 
of tool soaking for 2 hours. The arrest was carried out as many as 12 repetitions, meaning that one replication was the same as one trip. The placement of nets in the coral reef area is in accordance with the treatment with transverse or unidirectional shoreline. The composition of 10 species of coral fishes are Siganus canaliculatuis, Siganus spinus, Siganus chysospilos, Scarus fraenatus, Scarus quoyi, Lutjanus gibbus, Pristipomoides auricillia, Quoyanus Epinephelus, Mulloidichtys flavolineatus and Rhinecanthus verrucosus. The diversity of fish species caught on the coral reef ecosystem on Donrotu Island is classified as moderate, and no species dominates and the distribution of species is very evenly distributed. The gillnet minimum bottom net size for fishing in coral reef ecosystems with the size of fish is using nets with mesh size 3,78 inches and large, wide and high fish with a 5.30 inch mesh size and long and flat fish with a 2.65 ichi mesh size.

Keywords: Coral fish, the size of net mesh, Donrotu Island

\section{PENDAHULUAN}

Indonesia merupakan salah satu negara kepulauan yang termasuk kedalam segitiga terumbu karang dunia serta memiliki kekayaan sumber daya laut khususnya terumbu karang yang sangat potensial. Luas terumbu karang Indonesia sebesar $42.000 \mathrm{~km} 2$ atau 16,5\% dari luasan terumbu karang dunia (Setiawan $d k k, 2017$ ).

Keberadaan ekosistem ini memberikan manfaat kepada masyarakat secara ekologi, ekonomi dan sosial. Manfaat lain yang diperoleh yaitu berlimpahnya ikan didaerah sekitar terumbu karang. Hal ini dikarenakan, ikan menjadikan terumbu karang sebagai habitat. Terumbu karang bisa dijadikan ikan dan biota laut lainnya sebagai daerah pencari makanan, persinggahan maupun asuhan. Terumbu karang merupakan penyuplai nutrien terpenting dalam perairan. Selain itu terumbu karang juga berfungsi sebagai pelindung pantai dari degradasi dan abrasi. Berbagai macam larva ikan bisa tumbuh dan berkembang didaerah terumbu karang (Nasir $d k k ., 2017$ ).

Ikan karang merupakan salah satu organisme laut yang hidup dan berkembang didaerah terumbu karang. Komunitas ikan karang merupakan bagian yang penting dalam menjaga keseimbangan dengan berbagai komponen penyusun ekosistem terumbu karang. Dari perkiraan 12.000 spesies ikan laut dunia, kurang lebih 7.000 spesies $(58,3 \%)$ merupakan ikan yang hidup didaerah terumbu karang, tetapi tidak semua ikan tersebut hidup dalam satu habitat yang sama (Allen, 2005 dalam Akbar $d k k, 2018)$.

Jenis ikan karang dapat dibagi dalam tiga kelompok yaitu kelompok jenis indikator (Famili Chaetodontidae), kelompok ikan target (Famili Lutjanidae, Siganidae, Acanthururidae, Mullidae, Scolopsidae) dan kelompok ikan yang berperan dalam rantai makanan (sebagian besar Famili Pomacantridae) (Adrim, 1993.Penelitian ikan karang di Indonesia telah banyak dilaporkan. Salah satunya diwilayah Malulu Utara seperti Ratnawati $d k k$ (2011) di Kepulauan Kayoa, LIPI (2012) di perairan Ternate, Tidore dan sekitarnya, Najamuddin $d k k$ (2012) di perairan pulau Makian dan Akbar $d k k$ (2018) di Pulau Maitara.

Salah satu alat tangkap yang digunakan dalam penangkapan ikan pada ekosistem terumbu karang adalah jaring insang dasar (Bottom gillnet). Jaring insang dasar (bottom gillnet) adalah jaring insang yang dioperasikan (direntangkan) dekat dasar perairan laut yang ditujukan untuk menangkap jenis ikan demersal dan jenis ikan karang. Selanjutnya dinyatakan bahwa ikan yang 
menjadi tujuan usaha penangkapan dari perikanan jaring insang (gillnet) adalah jenis ikan baik bermigrasi horisontal maupun vertikal, vertikalnya tidak seberapa aktif dan terbatas pada suatu kisaran lapisan kedalaman tertentu (Monintja et al. 1996dalam Yasmi, 2009).

Jaring insang (gillnet) adalah jaring yang berbentuk empat persegi panjang yang dilengkapi pemberat-pemberat pada tali ris bawah dan pelampungpelampung pada tali ris atas. Gillnet dipasang tegak lurus terhadap permukaan air dan menghadang arah gerak ikan. Ikan-ikan yang tertangkap gillnet disebabkan tersangkut pada suatu mata jaring atau tergulung oleh jaring. Keberhasilan penangkapan ikan kembung dengan menggunakan gillnet tergantung pada ukuran mata jaring (mesh size) yang digunakan dan cara tertangkap (Making $d k k$, 2014).

Pada alat tangkap jaring insang dengan sistem penangkapan menjerat ikan, ukuran mata jaring sama dengan lingkar badan. Akan tetapi pada alat tangkap dimana jaring berfungsi sebagai dinding, ukuran mata jaring harus lebih kecil dari lingkar badan (Atmaja dan Haluan, 2003)..Tujuan dari penelitian ini adalahmengetahui jenis-jenis ikan yang hidup di terumbu karang yang tertangkap dengan jaring insang dasar, mengetahui struktur komunitas ikan pada ekosistem terumbu karang yang meliputi keanekaragaman jenis, dominasi jenis, kemerataan jenis) dan menentukan ukuran mata jaring minum dari alat tangkap bottom gillnet yang dioperasikan pada ekosistem terumbu karang di Pulau Donrotu Desa Sidangoli Dehe.

\section{Metode Penelitian}

\subsection{Waktu dan tempat penelitian}

Penelitian ini dilaksanakan di perairan Desa Sidangoli Dehe Kecamatan Jailolo Selatan Kabupaten Halmahera Barat. Waktu pelaksanaan penelitian selama 6 bulan yaitu April-September 2018.

Jaring dioperasikan pada waktu siang dan malam hari pada saat air bergerak pasang. Penangkapan dilakukan sebanyak 12 kali ulangan artinya satu kali ulangan sama dengan satu trip. Penempatan jaring di depan areal terumbu karang dengan melintang atau searah garis pantai. Proses penangkapan dengan bantuan perahu dan tenaga dari beberapa orang.Urutan penurunan alat dimulai dengan melepaskan pelampung terlebih dahulu sebagai tanda kemudian tali pelampung jaring tersebut dibiarkan menetap didasar perairan selama 3 jam. Sebelum meninggalkan lokasi, dilakukan pengecekkan ulang untuk memastikan apakah alat tangkap yang dilepaskan berada pada posisi yang tepat sesuai dengan direncanakan. Hasil tangkapan yang diperoleh dimasukan ke dalam Cool box yang telah diberi es batu dan dibawa ke daratan untuk dideterminasi berdasarkan petunjuk Peristiwady (2006) dengan melihat ciri-ciri morfologi seperti warna tubuh, bentuk tubuh dan bentuk ekor. Ikan hasil determinasi selanjutnya dihitung jumlahnya serta dipisahkan berdasarkan famili, genus dan spesies.

Metode analisi data meliput :

Keanekaragaman digunakan metode Shannon dan Wiener (Rondo, 2015), sebagai berikut :

$$
H^{\prime}=-\sum_{i: 1}^{s} \frac{n i}{N} \ln \frac{n i}{N}
$$

Keterangan: 
$\mathrm{H}=$ Keanekaragaman jenis, $\mathrm{ni}=$ Jumlah indivivu jenis-i, $\mathrm{N}=$ Jumlah seluruh individu

Dengan kriteria $: H^{\prime}<1=$ Keanekaragaman jenis rendah, $1 \leq H^{\prime} \leq 3=$ Keanekaragaman jenis sedang, $H^{\prime}>3=$ Keanekaragaman jenis tinggi.

Dominasi spesies adalah penyebaran jumlah individu tidak sama dan ada kecenderungan suatu spesies mendominasi. Untuk mengetahui indeks dominasi menurut Rondo (2015) adalah :

Keterangan :

$$
C=\sum\left(\frac{n i}{N}\right)^{2}
$$

$$
\begin{aligned}
\mathrm{C}= & \text { Dominansi jenis, } \mathrm{ni}=\mathrm{Jumlah} \text { individu tiap jenis, } \mathrm{N}=\text { Jumlah } \\
& \text { individu seluruh jenis. }
\end{aligned}
$$

Kemerataan jenis digunakan untuk melihat penyebaran setiap organisme pada suatu habitat yang ditempati. Kemerataan jenis mengikuti formula (Wibisono, 2005) sebagai berikut :

Keterangan :

$$
E=\frac{H^{\prime}}{H_{\max }}
$$

$\mathrm{E}=$ Indeks kemerataan, $\mathrm{H}^{\prime}=$ Keanekaragaman jenis, $\mathrm{H}_{\max }=\mathrm{Ln} \mathrm{S}$,

$\mathrm{S}=$ Jumlah taksa.

\subsection{Penentuan Ukuran Mata Jaring}

Hubungan antara body girth dengan panjang cagak dianalisis dengan menggunakan regresi liniear sederhana (Steel and Torrie, 1982dalam Musbir $d k k$, 2006) dengan persamaan sebagai berikut:

Keterangan:

$$
Y=a+b X
$$

$$
\mathrm{Y}=\text { Panjang cagak (mm), } \mathrm{X}=\text { Lingkar badan }(\text { Body girth) }(\mathrm{mm})
$$

Untuk menentukan ukuran mata jaring digunakan rata-rata panjang cagak karena ikan yang tertangkap pada ekosistem terumbu karang memiliki ukuran yang bervariasi. Rata-rata panjang cagak dibagi dengan nilai konstanta masingmaisng ukurang sehingga dapat menghasilkan ukuran mata jarring yang sesuai dengan ukuran ikan (BBPPI, 2009). Adapun kriteria yaitu :

- Ikan sedang dengan konstanta 3,5.

- Ikan besar, lebar dan tinggi dengan konstanta 2,5.

- Ikan panjang dan pipih dengan konstanta 5.

\section{Hasil Dan Pembahasan}

\subsection{Komposisi Jenis Ikan Hasil Tangkapan}

Penangkapan yang dilakukan selama 12 trip penangkapan, secara keseluruhan diperoleh komposisi jenis ikan sebanyak 2 ordo, 6 famili dan 10 jenis. Komposisi jenis hasil tangkapan disajikan pada Tabel 1.Famili Siganidae dan Scaridae memiliki jumlah jenis lebih banyak yaitu masing-masing 3 jenis. Famili Siganidae terdiri dari jenis (Siganus canaliculatuis, Siganus spinus, Siganus chysospilos). Selanjutnya diikuti olehfamili Scaridae (Scarus fraenatus, Scarus quoyi,) dan famili Lutjanidae (Lutjanus gibbus, Pristipomoides auricillia). Sedangkan famili yang memiliki komposisi jenis terendah masing-masing 
terdapat pada famili Symphysanodontidae (Epinephelus quoyanus), Mullidae (Mulloidichtys flavolineatus) dan famili Balistidae (Rhinecanthus verrucosus).

Tabel 1. Komposisi jenis ikan yang tertangkap

\begin{tabular}{|c|c|c|c|c|c|}
\hline \multirow{2}{*}{ No. } & \multirow{2}{*}{ Ordo } & \multirow{2}{*}{ Famili } & \multicolumn{3}{|c|}{ Nama } \\
\hline & & & Spesies & Indonesia & Lokal \\
\hline 1 & Perciformes & Siganidea & Siganus canaliculatus & Beronang & Uhi \\
\hline 2 & Perciformes & Siganidea & Siganus spinus & Beronang & Uhi putih \\
\hline 3 & Perciformes & Siganidea & Siganus chrysospilos & Beronang & Samandar lebar \\
\hline 4 & Perciformes & Symphysanodontidae & Epinephelus quoyanus & Kerapu tutul & Goropa \\
\hline 5 & Perciformes & Scaridae & Scarus fraenatus & Kakatua biru & kakatua \\
\hline 6 & Perciformes & Scaridae & Scarus quoyi & Kakatua & Kakatua \\
\hline 7 & Perciformes & Mullidae & Mulloidichtys flavolineatus & Biji nangka & Biji nangka \\
\hline 8 & Perciformes & Lutjanidae & Lutjanus gibbus & Jenaha & Gace \\
\hline 9 & Perciformes & Lutjanidae & Pristipomoides auricillia & Tariasan & Tariasan \\
\hline 10 & Tetraodontiformes & Balistidae & Rhinecanthus verrucosus & Tato & Tato \\
\hline $\mathrm{Jlh}$ & 2 Ordo & 6 Famili & 10 spesies & & \\
\hline
\end{tabular}

Komposisi jenis ikan yang tertangkap ada sebagian ikan yang hidup pada ekosistem padang lamun dan memiliki komposisi jenis lebih tinggi yaitu famili Siganidae. Hal ini disebabkan karena ekosistem terumbu karang berdekatan dengan ekosistem padang lamun sehingga ikan dari Family Siganidae memanfaatkan areal terumbu karang untuk mencari makan.

Abubakar dan Ahmad (2013) menyatakan bahwa mangrove, terumbu karang dan padang lamun (sea grass) merupakan tiga ekosistem penting di pesisir. ketiganya saling berinteraksi dan membentuk suatu kesatuan ekosistem yang erat. Interaksi tersebut dapat berupa fisik, biologi maupun kimia. Lebih lanjut dikatakan bahwa secara biologi, terjadi interaksi antara ketiga habitat tersebut dalam menyediakan ruang dan media hidup bagi organisme laut. Organisme laut dalam berbagai tingkatan hidupnya bermigrasi dari dan ke masing-masing habitat, tipe migrasinya dapat dikelompokkan antara lain (1) migrasi sementara untuk mencari makan dan (2) migrasi tahapan hidup (larvae, post larva, juvenile, dewasa).

Komposisi jenis ikan yang tertangkap merupakan jeni ikan target yang selalau dimanfaatkan oleh masyarakat dan ikan indikator (famili Cahetodontidae). Sebagaimana Allen (2000) menyatakan bahwa ikan yang menjadi target dalam penangkapan yaitu ikan yang memiliki nilai ekonomis dan dapat dikonsumsi oleh nelayan seperti family Serranidae, Lutjanidae, Kyphosidae, Lethrinidae, Acanthuridae, Mulidae, Siganidae, Labridae dan Haemulidae. Sedangkan ikan indikator yaitu jenis-jenis ikan karang sebagai penentu kesuburan terumbu karang. Ikan ini juga sering dimanfaatkan misalnya ikan dari family Chaetodontidae (Kepe-kepe).

Komposisi jenis ikan yang tertangkap merupakan ikan yang memiliki nilai ekonomis karena selalu dikonsumsi oleh masyarakat Desa Sidangoli Dehe. Harga jual ikan bervariasi tergantung ukurannya, hasil pengamatan kisaran harga ikan yang tertangkap Rp. 10.000-20.000/ ekor.

Ilyas $d k k$ (2017), menyatakan ikan karang target adalah ikan ekonomis tinggi yang biasa ditangkap untuk dikonsumsi, seperti ikan baronang, kerapu, kakap, ikan bibir tebal, ikan ekor kuning. Lebih lanjut dikatakan Utomo $d k k$ (2013) bahwa bagi masyarakat sekitar ekosistem terumbu karang, ikan karang 
merupakan salah satu sumberdaya penghasil kebutuhan hidup mereka. Beberapa jenis ikan karang yang dikonsumsi adalah dari suku Serranidae (Kerapu), Caesionidae, (Ekor Kuning/ Pisang-Pisang), Scaridae (Kakatua/ Mogong), Balistidae (Poge/ Trigger), Pomacanthidae (Enjel/ Kambingan), dan Siganidae (Baronang/ Kea-Kea/ Lingkis).Selain sebagai ikan konsumsi beberapa jenis ikan karang juga dimanfaatkan sebagai ikan hias dan sebagai penentu kesuburan terumbu karang yaitu dari family Chaetodontidae (Kepe-kepe).

\subsection{Keanekaragaman Jenis, Dominasi Jenis dan Kemerataan Jenis}

Struktur komunitas ikan yang tertangkap pada ekosistem terumbu karang, diperoleh $\mathrm{H}^{\prime}=2,21$, dominansi jenis $\mathrm{C}=0,12$ dan kemerataan jenis $\mathrm{E}=0,96$. Hail ini menunjukan keanekaragaman jenis ikan yang tertangkap pada ekosistem terumbu karang Pulau Donrotu tergolong sedang, dan tidak ada jenis yang mendominasi serta penyebaran jenisnya sangat merata (Tabel 2).

Menurut Rondo (2015) bahwa indeks keanekaragaman jenis adalah ukuran kekayaan komunitas dilihat dari jumlah spesies dalam suatu komunitas, berikut jumlah individu dalam tiap spesies. bahwa jika $1<\mathrm{H}^{\prime}<3$, maka keanekaragaman sedang dan jika nilai $\mathrm{C}$ mendekati 0 berarti tidak ada spesies yang mendominasi dan apabila nilai $\mathrm{C}$ mendekati 1 berarti adanya salah satu spesies yang mendominasi. Lebih lanjut menurut Wibisono (2005), bahwa nilai kemerataa $>0,81$ menunjukkan penyebaran jenis sangat merata.

Tabel 2. Hasil analisis keanekaragaman jenis (H'), dominansi jenis (C) dan kemerataam jenis (E) ikan karang

\begin{tabular}{|c|c|c|c|c|c|}
\hline No & Jenis & $\mathrm{H}^{\prime}$ & $\mathrm{C}$ & $\mathrm{E}$ & \\
\hline 1 & Siganus canaliculatus & 0.28 & 0.022 & \multirow{10}{*}{$\begin{array}{l}\mathrm{H}^{\prime}= \\
\mathrm{Hmax}=\end{array}$} & \multirow{10}{*}{$\begin{array}{l}2.21 \\
2.30\end{array}$} \\
\hline 2 & Siganus spinus & 0.20 & 0.006 & & \\
\hline 3 & Siganus chrysospilos & 0.18 & 0.004 & & \\
\hline 4 & Epinephelus quoyanus & 0.25 & 0.014 & & \\
\hline 5 & Scarus fraenatus Lacepede & 0.24 & 0.011 & & \\
\hline 6 & Scarus quoyi valenciennes & 0.22 & 0.009 & & \\
\hline 7 & Mulloidichtys flavolineatus & 0.20 & 0.006 & & \\
\hline 8 & Lutjanus gibbus & 0.32 & 0.040 & & \\
\hline 9 & Pristipomoides auricillia & 0.18 & 0.004 & & \\
\hline 10 & Rhinecanthus verrucosus & 0.13 & 0.002 & & \\
\hline & Total & 2.21 & 0.12 & 0.96 & \\
\hline
\end{tabular}

Keanekaragaman jenis yang diperoleh dipengaruhi oleh jumlah jenis serta jumlah individu yang diperoleh tidak banyak. Selain itu juga dipengaruhi oleh selektivitas alat yang digunakan dengan ukuran mesh size yang sama sehingga jenis-jenis ikan yang tertangkap hanya pada ukuran yang sama (2,5 inch).

Menurut Abubakar dkk (2018), bahwa suatu komunitas dikatakan mempunyai keanekaragaman yang tinggi jika komunitas itu disusun oleh banyak spesies, sebaliknya jika komunitas itu disusun oleh sedikit spesies maka keanekaragamannya rendah. Lebih lanjut dikatakan Menurut Odum (1971) dalam 
Setiawan $d k k$ (2017) bahwa semakin besar nilai keanekaragaman (H') menunjukkan komunitas semakin beragam dan indeks keanekaragaman tergantung dari variasi jumlah spesies yang terdapat dalam suatu habitat

Nilai dominasi yang didapat dipengaruhi tersebut berhubungan dengan nilai keanekaragaman jenis yang diperoleh, artinya apabila keaneragaman jenis yanmg diperoleh tinggi maka dominasinya rendah, begitu juga sebaliknya. Menurut Abubakar $d k k$ (2018) bahwa indeks keanekaragaman jenis berbanding terbalik dengan indeks dominasi, yaitu indeks keanekaragaman jenis yang tinggi di suatu tempat, maka pada tempat itu tidak terdapat spesies yang dominan, begitu juga sebaliknya apabila keanekaragaman jenis rendah maka ada jenis yang mendominasi.

Indeks keseragaman (E) menggambarkan ukuran jumlah individu antar spesies dalam suatu komunitas ikan. Semakin merata sebaran individu antar spesies maka keseimbangan komunitas akan semakin baik (Odum, 1971 dalam Rondo, 2015).

Kemeratan jenis yang diperoleh, menunjukkan bahwa semua jenis ikan yang tertangkap memiliki penyebaran sangat merata. Hal ini menunjukkan keseimbangan komunitas ikan yang hidup pada skosistem terrumbu karang dalam kondisi semakin baik. Sebagaimana Wibisono (2005), menyatakan bahwa nilai kemerataa $>0,81$ menunjukkan penyebaran jenis sangat merata. Lebih lanjut dikatakan (Setyobudiandy et al. 2009 dalam Setiawan dkk, 2017) bahwa nilai indeks keseragaman (E) menunjukkan kesetabilan sebuah komunitas. Nilai E dimana semakin mendekati 1 menunjukan komunitas semakin stabil dan jika semakin mendekati 0 , maka komunitas semakin tertekan

\subsection{Penentuan Ukuran Mata Jaring}

Hasil pengukuran panjang ikan karang hasil tangkapan berkisar antara 125-331 mm dan lingkar badan berkisar antara 63-291 mm. Penentuan ukuran mata jaring (mesh size) didasarkan pada ukuran lingkar badan ikan. Bila ukuran lingkar kepala ikan (Body girth) sama dengan ukuran mata jaring maka ikan akan terjerat pada jaring. Dari hasil pengukuran antara panjang ikan dan ukuran lingkar badan didapatkan persamaan regresi $\mathrm{Y}=68,18+0,82 \mathrm{X}$, artinya bahwa apabila panjang cagak bertambah sebesar $1 \mathrm{~mm}$, maka body girth juga akan bertambah sebesar $0,82 \mathrm{~mm}$.

Hasil analisis hubungan antara panjang cagak dengan lingkar badan ikan yang tertangkap pada ekosistem terumbu karang dengan menggunakan jaring insang dasar didapatkan hubungan yang linier. Menurut Hasan (2002), bahwa koefisien korelasi (r) digunakan untuk melihat sejauh mana keeratan hubungan dari dua variabel. Hasil analisis koefisien korelasi yang diperoleh menunjukkan bahwa variabel panjang cagakmemiliki hubungan yang sangat erat dengan lingkar badan (body girth), artinya bahwa setiap peningkiatan body girth selalu diikuti oleh panjang cagak. Hasan (2002), menyatakan bahwa bila harga $\mathrm{r}=0,70<\mathrm{KK} \leq$ 0,90, maka korelasi tinggi, atau kuat. Lebih lanjut dikatakan Omar $d k k$ (2015) bahwa lingkar badan ikan di belakang operkulum digunakan sebagai rujukan dalam penentuan ukuran mata jaring minimum.

Menurut Najamudin $d k k(2004)$ bahwa lingkar badan ikan diukur sebagai patokan dalam penentuan ukuran mata jaring. Pada umumnya ikan akan terjerat pada jaring apabila lingkar kepala ikan sama dengan ukuran mata jarring. Berdasarkan hasil analisis koefisien determinasi menunjukkan bahwa $63 \%$ 
perubahan panjang cagak disebabkan perubahan lingkar badan (Body girth). Koefisien determinasi $\left(\mathrm{R}^{2}\right)$ atau derajat hubungan menjelaskan besarnya pengaruh nilai suatu variabel (variabel $\mathrm{X}$ ) terhadap naik/turunnya nilai variabel lainnya (variabel Y) (Hasan, 2002).

Berdasarkan rata-rata ukuran panjang cagakyaitu 206,19 mm maka dapat direkomendasikan bahwa untuk penangkapan ikan di ekosistem terumbu karang dengan ukuran ikan sedang dengan menggunakan jaring dengan mesh size 2,36 inchi dan ikan besar, lebar dan tinggi dengan mesh size 3,30 inchi serta ikan yang panjang dan pipih dengan mesh size 1,65 ichi.

Menurut Ayodhyoa (1981 dalam Making dkk (2014) bahwa antara mesh size dan besar ikan terdapat hubungan yang erat atau dengan perkataan lain gillnet akan bersifat selektif terhadap ukuran dari ikan yang diperoleh. Jadi dalam melakukan suatu penangkapan dengan mengunakan gillnet hal penting yang perlu diperhatikan adalah penggunaan mesh size yang tepat sehingga ikan-ikan kecil diberi kesempatan untuk lolos sehingga tidak terjadi overfishing dikemudian hari.

Ukuran mata jaring erat hubungannya dengan ukuran ikan yang tertangkap secara terjerat. Ukuran mata jaring tetentu cenderung untuk menjerat ikan yang mempunyai panjang garpu (fork length) tertentu pula. Beberapa peneliti melaporkan bahwa terdapat korelasi nyata antara ukuran mata jaring insang terhadap ukuran panjang garpu (fork length) dan keliling badan ikan yang tertangkap. Rahantan dan Puspito (2012) menyatakan bahwa kisaran ukuran ikan yang tertangkap oleh suatu ukuran mata jaring tertentu dapat diprediksi berdasarkan pada hubungan antara panjang garpu (fork length) dan keliling badan ikan.

Untuk mencegah kemungkinan gangguan terhadap kelestarian sumberdaya ikan yang hidup pada ekosistem terumbu karang secara ideal. Dalam rangka mempertahankan keberlanjutan populasi ikan pada ekosistem terumbu karang di perairan Pulau Donrotu perlu penerapan peraturan penggunaan ukuran mata jaring minimum sesuai dengan ukuran ikan

\section{Kesimpulan}

Komposisi jenis ikan terumbu karang sebanyak 10 jenis yaituSiganus canaliculatuis, Siganus spinus, Siganus chysospilos, Scarus fraenatus, Scarus quoyi,Lutjanus gibbus, Pristipomoides auricillia, Epinephelus quoyanus, Mulloidichtys flavolineatusdan Rhinecanthus verrucosus. Keanekaragaman jenis ikan yang tertangkap pada ekosistem terumbu karang di Pulau Donrotu tergolong sedang, dan tidak ada jenis yang mendominasi serta penyebaran jenisnya sangat merata.Ukuran mata jaring minimum bottom gillnet untuk penangkapan ikan pada ekosistem terumbu karang dengan ukuran ikan sedang menggunakan jaring dengan mesh size 3,78 inchi dan ikan besar, lebar dan tinggi dengan mesh size 5,30 inchi serta ikan yang panjang dan pipih dengan mesh size 2,65 ichi.

\section{Daftar Pustaka}

Atmaja SB dan Haluan J. 2003. Perubahan Hasil Tangkapan Lestari Ikan Pelagis di Laut Jawa dan Sekitarnya. Fakultas Perikanan dan Ilmu Kelautan. IPB.Buletin PSP Vol XII No. 2. Hal 31-40. 
Abubakar, S dan A. Achmad. 2013. Tumbuhan Air(Panduan Pengajaran).LepKhair. Universitas Khairun. Ternate.

Abubakar, S, M. Abdul kadir, n. Akbar dan I. Tahir. 2018. Asosiasi Dan Relung Mikrohabitat Gastropoda Pada Ekosistem Mangrove Di Pulau Sibu Kecamatan Oba Utara Kota Tidore Kepulauan Provinsi Maluku Utara. Jurnal Enggano E-ISSN: 2527-5186. P-ISSN:2615-5958 Vol. 3, No. 1, April 2018. Hlm : 22-38.

Adrim, M. 1993. Pengantar Studi Ekologi Komunitas Ikan Karang dan Metode Pengkajian dalam Kursus Pelatihan Puslitbang Oseanologi. Lembaga Ilmu Pengetahuan Indonesia. Jakarta.

Akbar, N, F. Ismail dan R. E Paembonan. 2018. Struktur Komunitas Ikan Karang di Perairan Pulau Maitara, Kota Tidore Kepulauan. Provinsi Maluku Utara. Jurnal Ilmu Kelautan Kepulauan, 1 (1) ; 1-14, Juni 2018 ISSN 2620-570X. 1-14 hal.

Allen, G. 2000. Panduan Dasar Untuk Pengenalan IKan Karang. Terangi Indonsesia (Terjemahan).

Hasan, M. I. 2002. Pokok-Pokok Materi Statsitik 2 (Statsitik Inferensi). Edisi kedua. Bumi Aksara. Jakarta.

Ilyas, I. S, Sri A, Syawaludin A. H dan Noir P. P. 2017. Keanekaragaman Ikan Karang Target Kaitannya Dengan Keanekaragaman Bentuk Pertumbuhan Karang Pada Zona Inti Di Taman Wisata Perairan Kepulauan Anambas. Jurnal Perikanan dan Kelautan Vol. VIII No. 2 /Desember 2017(103-111)

Lembaga Ilmu Pengetahuan Indonesia. 2016. Monitoring Kesehatan Terumbu Karang dan Ekosistem Terkait Perairan Ternate dan Sekitarnya, Provinsi Maluku Utara. LIPI ; Pusat Penelitian Oseanografi, Jakarta. 66 Hal.

Making, A.D.L, Asriyanto dan Taufik, Y. 2014. Pengaruh Perbedaan Mata Jaring (Mesh size) Gillnet Terhadap Cara Tertangkap Ikan Kembung Perempuan (Scomber neglectus) Di Perairan Morodemak Kabupaten Demak. Journal of Fisheries Resources Utilization Management and Technology. Volume 3, No. 4 Tahun 2014. h. 120-129.

Musbir, Mallawa, A., Sudirman, Najamudin. 2006. Pendugaan Ukuran Pertama Kali Matang Gonad Ikan Kembung, Rastrelliger kanagurta Di Perairan Laut Flores Sulawesi Selatan. Program Pasca Sarjana Jurusan Sains dan Teknologi, Fakultas Ilmu Kelautan dan Perikanan, Universitas Hasanuddin. Makassar.April 2006, Vol. 6 No. 1: 19 - 26 ISSN 14114674

Najamuddin, Ishak S dan Ahmad A. 2012. Keragaman ikan karang di perairan Pulau Makian Provinsi Maluku Utara. Jurnal Depik, 1(2): 114-120.

Najamuddin, Mallawa, A., Budimawan, Indar, M. Y. N. 2004. Pendugaan Ukuran Pertama Kali Matang Gonad Ikan Layang Deles (Decapterus macrosoma Bleeker). Program Pasca Sarjana Jurusan Sains dan Teknologi, Fakultas Ilmu Kelautan dan Perikanan, Universitas Hasanuddin. Makassar. April 2004, Vol. 4 No. 1:1-8. ISSN 1411-4674. 
Nasir M, Zuhal M dan Ulfah M. 2017. Struktur komunitas ikan karang di perairan Pulau Batee Kecamatan Peukan Bada Kabupaten Aceh Besar. Bioleuser, $1(2): 76-85$.

Omar, S. B. A, M. N. Moh, T. Umar, Muh. A. Dahlan dan Syarifuddin Kune. 2015. Nisbah Kelamin Dan Ukuran Pertama Kali Matang Gonad Ikan Endemik Pirik (Lagusia micracanthus bleeker, 1860) Di Sungai Pattunuang, Kabupaten Maros dan Sungai Sanrego, Kabupaten Bone Sulawesi selatan. Seminar Nasional Tahunan XII Hasil Penelitian Perikanan dan Kelautan, 08 Agustus 2015. Semnaskan_Universitas Gajahmada.

Peristiwady, T. 2006. Ikan-Ikan Laut Ekonomis Penting di Indonesia. Petunjuk Identifikasi. Penerbit LIPI. Jakarta.

Rahantan, A dan Puspita, G. 2012. Ukuran Mata dan Shortening Yang Sesuai Untuk Jaring Insang Yang Dioperasikan Di Perairan Tual. Jurnal Mrine Fisheries Vol. 3, No. 2 November 2012.

Ratnawati P, Priliska H dan Sukmaraharja. 211. Kondisi dan Potensi Komunitas Ikan Karang di Wilayah Kepulauan Kayoa, Kabupaten Halmahera Selatan Maluku Utara. Prosiding Seminar Nasional, 11-22 Hal.

Rondo, M. 2015. Metodologi Analisis Ekologi Populasi dan Komunitas Biota Perairan. Program Pascasarjana. Unsrat. Manado.

Setiawan, F, A. Muttaqin, Estradivari, E. Muttaqin, S. A. Tarigan, T. Wijanarko, Khaifin, N. Wisesa2, A.Y. Retrawimbi, Muhidin, H. Akhrari dan S. Sadewa. 2017. Biodiversitas ikan karang di wilayah bentang laut lesser sunda banda (kab. Flores timur, alor dan maluku barat daya (mbd)), Indonesia. Jurnal Kelautan Volume 10, No. 1, 2017 ISSN: 1907-9931 (print), 2476-9991 (online). 1-20 hal.

Utomo, S.P.R, C.Ain dan Supriharyono. 2013. Keanekaragaman Jenis Ikan Karang Di Daerah Rataan Dan Tubir Pada Ekosistem Terumbu Karang Di Legon Boyo, Taman Nasional Karimunjawa, Jepara. Diponegoro Journal Of Maquares Volume 2, Nomor 4, Tahun 2013, Hal 81-90.

Wibisono, M.S. 2005. Pengantar Ilmu Kelautan. Penerbit PT. Gramedia Widiasarana. Jakarta.

Yasmi, M. 2009. Studi Perbedaan Habitat Terhadap Hasil Tangkapan IKan Beronang (Siganus sp)dengan Gillnet di Perairan Kepulauan Guraici Kecamatan Kayoa Kabupaten Halmahera Selatan Provinsi Maluku Utara. Program Studi PSP FPIK Unkhair. Ternate. 